Dokuz Eylül Üniversitesi-Mühendislik Fakültesi Fen ve Mühendislik Dergisi

Cilt 20, Sayı 59, Mayıs, 2018
Dokuz Eylul University-Faculty of Engineering Journal of Science and Engineering Volume 20, Issue 59, May, 2018

DOI: $10.21205 /$ deufmd. 2018205924

\title{
Betonarme Yapılarda Burkulması Önlenmiş Çelik Çapraz Elemanların Doğrusal Olmayan Davranıșa Etkisi
}

\author{
Bilge DORAN ${ }^{1}$, Erkan ŞENOL*2, İsmail KÖSE ${ }^{3}$ \\ ${ }^{1}$ Ylldız Teknik Üniversitesi, İnşaat Fakültesi, İnşaat Mühendisliği Bölümü, 34220, \\ İstanbul (ORCID: 0000-0001-6703-7279) \\ ${ }^{2}$ Ylldız Teknik Üniversitesi, İnşaat Fakültesi, İnşaat Mühendisliği Bölümü, 34220, \\ İstanbul (ORCID: 0000-0002-3290-945X) \\ ${ }^{3}$ Yıldız Teknik Üniversitesi, İnşaat Yüksek Mühendisi, 34220, İstanbul (ORCID: 0000- \\ 0002-4228-0173) \\ (Alınıș / Received: 15.09.2017, Kabul / Accepted: 22.03.2018, \\ Online Yayınlanma / Published Online: 15.05.2018) \\ Anahtar Kelimeler özet: Burkulması önlenmiş çaprazlar, sismik ve/veya diğer yükler \\ Burkulması \\ önlenmiş çapraz, \\ Betonarme \\ yapilar, \\ İtme analizi, \\ Performans \\ değerlendirmesi \\ altında gerekli dayanımı sağlamak üzere kullanılan kullanışlı yapı \\ elemanlarıdır. Önemli oranda süneklik kapasitesine sahip bu \\ elemanlar deprem durumunda oluşan plastik șekil değiștirmelerin \\ azaltılmasına da yardımcı olur. Her ne kadar literatürde yeterli \\ bilgi olmasa da, yeni betonarme binaların tasarımında veya \\ güçlendirme amaçlı olarak mevcut betonarme binalarda \\ Burkulması önlenmiş çapraz elemanlar ile çerçeveler beraber \\ kullanılabilmektedir. Bu çalışma kapsamında farklı kat sayılarına \\ sahip (az/orta katlı) örnek betonarme yapılarda farklı şekilde \\ uygulanmış Burkulması önlenmiş çapraz elemanlarla birlikte \\ çerçeve davranıșı doğrusal olmayan statik analiz ile incelenmiştir.
}

\section{Effect of Buckling Restrained Steel Braces on Nonlinear Behavior of Reinforced Concrete Structures}

\begin{tabular}{l}
\hline Keywords \\
Buckling \\
restrained \\
brace, \\
Reinforced \\
concrete \\
structures, \\
Push-over \\
analysis, \\
Performance \\
based \\
evaluation
\end{tabular}

1. Giriş

Büyük bir bölümü deprem kuşağında bulunan ülkemiz için, mevcut betonarme yapıların güçlendirilmesi konusu, güçlü

\begin{abstract}
Buckling Restrained Braces are useful structural components when providing bracing for seismic or other loads. Buckling Restrained Braces which have a large ductility capacity are helped to decrease the plastic deformations due to seismic loadings. Although the literature information is limited for the reinforced concrete structures, frame with Buckling Restraint Braces are being used for a new and existing reinforced concrete buildings. In this study, Buckling Restraint Braces which are implemented to reinforced concrete sample structures having different number of stories (low/medium-rise) with different configurations are examined using nonlinear static analysis process.
\end{abstract}

depremlerin oluşması durumunda ülkemiz ekonomisinin en az zarara uğraması ve can güvenliğinin en üst seviyede sağlanması açısından büyük

*Erkan Şenol: esenol@yildiz.edu.tr; esenol@inm.yildiz.edu.tr 
önem taşımaktadır. Teknolojinin gelişmesine paralel olarak dünyada ve ülkemizde son yirmi yıllık zaman diliminde, betonarme yapı ve yapı elemanlarının güçlendirilmesi konusunda yeni yöntem ve uygulama teknikleri ortaya çıkmıştır. Anılan teknikler büyük ölçüde tasarımcının inisiyatifine bırakılmıștır; hasarlı yapı için çlkarılacak "Hasar Rölevesi" doğrultusunda çatlakların gelişimi belirlenecek ve nedenleri tespit edilerek uygun bir yöntem doğrultusunda eleman onarımı/güçlendirilmesi veya sistem iyileştirilmesi benimsenecek, yapısal çözümlemeler sonucu her kat için hesaplanan yanal yer değiştirmeler sınır değerle, kolon ve kirișlerin eğilme ve kesme taşıma güçleri çözümden elde edilen değerle karşılaştırılarak yöntemin uygunluğu kanıtlanacaktır. Eleman onarımı/güçlendirilmesi öncelikli olarak kolon-kiriș elemanların eğilme ve kesme kapasiteleri artırmak amacıyla betonarme mantolama ve/veya çelik mantolama şeklinde düşünülmelidir. Sistem iyileştirmesi ise, çerçevelerden oluşan, yatay/düşey yükler açısından zayıf veya yetersiz bir taşıyıcı sistemin, rijit yatay/düşey elemanlardan oluşan yeni bir sistem olușturularak (betonarme perde ilavesi, çelik çapraz eleman ilavesi vs. ) mukavim hale getirilmesi olarak algılanmalıdır. Sistem iyileștirmesi, çok sayıda elemanın onarımı/güçlendirilmesi gerektiğinde ve/veya binanın yatay yüklere karşı göstermiş olduğu yanal rijitliğinin yetersiz olduğu durumlarda ortaya çıkmaktadır. Mevcut taşıyıcı sistemin, yumușak kat, zayıf kat, kısa kolon gibi bazı zayıflıkları içerdiği durumlarda da sistem iyileştirmesi tercih edilmektedir. Betonarme yapılarda depreme etkisine karşı yeterli yanal rijitliği sağlayacak betonarme perde ilavesi bilinen ve sik uygulanan bir yöntemdir. Diğer yandan, bir diğer yöntem olarak çelik çapraz eleman ilavesi gerek mevcut gerekse yeni tasarlanacak yapılarda farklı bir çözüm yolu olarak kullanılmaya başlanılmıştır. Çelik çapraz elemanlar için betonarme ve çelik sistem detayları sırası ile Şekil 1ve 2'de gösterilmiştir.

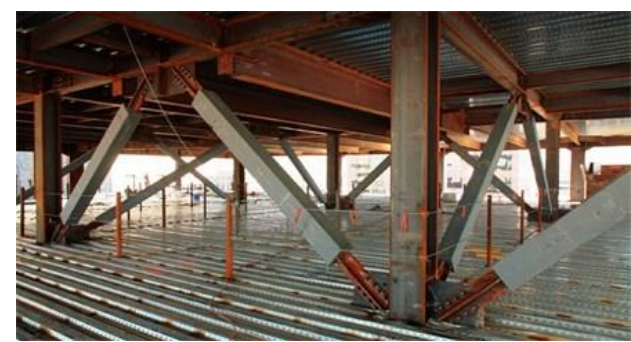

Şekil 1. Geleneksel çelik çapraz uygulaması [1]

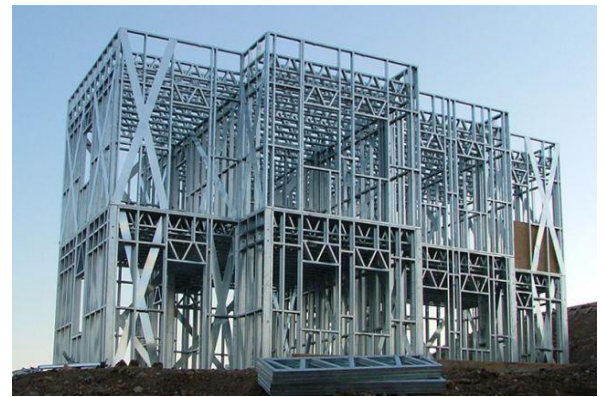

Şekil 2. Çelik çaprazlı çerçeve sistem yapı [2]

Ancak geleneksel olarak uygulanan çelik çaprazlı çerçeve sistemlerde, basınç kuvvetine maruz kalan elemanlar yerel burkulma nedeniyle taşıma gücüne erken ulaşmaktadır. Ayrıca Burkulma problemine karşı önlem olarak yapılan birbirine dik doğrultuda iki çelik çapraz kullanımı ise kullanılan malzeme miktarının ve maliyetin artmasına neden olmaktadır. Çelik çaprazların bu dezavantajını ortadan kaldırmak için çok sayıda çalışma yapılmıştır. Burkulması önlenmiş çaprazlar (BÖÇ) ilk defa Yashino ve Karino tarafından deneysel olarak çalışılmıştır. Bu çalışmada iki adet numune beton ile kaplanmıș ve çelik ile aderansı engellenerek, çelik elemanların sadece eksenel yükleri karşılaması, betonarme katmanın ise burkulmayı önlemesi sağlanmıştır [3]. Goel ve Lee [4] çelik sistemler kullanarak betonarme yapıların iyileştirilmesi ile ilgili gerçekleştirdikleri deneyler sonucunda 
sistemin betonarme yapının mukavemetini ve rijitliğini arttırdığını görmüşlerdir. Maheri ve Sahebi [5], betonarme yapılarda çelik çapraz kullanımını araştırmış ve betonarme ile çelik çaprazların uygun şekilde bağlanmasıyla çelik çaprazların deprem perdelerine alternatif olabileceği sonucuna ulaşmışlardır. Kim ve Choi, BÖÇ elemanlarla oluşturulmuş çelik çerçeve sistem için doğrusal olmayan analiz gerçekleştirerek enerji sönümleme kapasitesini ve deprem davranışını gözlemlemişlerdir. Çalışma sonucunda çaprazların rijitliği artarken yapının maksimum yer değiştirmelerinin azaldığını görmüșlerdir [6]. Qiang, BÖÇ elemanların çeşitli türlerini incelemiştir [7]. İncelemelerinde BÖÇ elemanların, hem çekme hem de basınç kuvvetleri altında aynı şekil değiştirme özelliklerini gösterdiğini ve kolay ayarlanabilir rijitlik ve mukavement özellikleriyle daha fazla enerji sönümlemeye sahip olduklarnı ortaya çıkarmışlardır.

Chang ve Chiu, 6 katlı BÖÇ elemanların kullanıldığı çelik bir yapının sismik davranışını inceleyerek BÖÇ elemanlar ile yapının hedeflenen yapı performans değerlerine ve can güvenliği performansına ulaşılabileceğini belirtmişlerdir [8]. Almansa ve diğerleri, nümerik bir model oluşturarak BÖÇ elemanları, eşmerkezli çaprazlara alternatif olarak kullanıp karşılaştırma yapmışlar ve bu karşılaştırmanın tatmin edici sonuçlar verdiğini belirtmişlerdir [9]. Hoveidae ve Rafezy, çeşitli açıklıklara ve kendilerine göre kusurlara sahip olan BÖÇ elemanlarda sonlu elemanlar analizi üzerine detaylı bir sunum yapmışlardır [10]. Khampanit, Leelataviwat, Kochanin ve Warnitchai, 5 katlı okul binasinda yerçekimi yükleri altında inceleme yaparak BÖÇ elemanların gözle görülür derecede yanal kuvvet kapasitesini ve enerji sönümlemelerini arttırdığını gözlemlemişlerdir [11]. Zhang, Wu, Mei ve Shing, yaptıkları bir araştırmada BÖÇ ile güçlendirilmiş betonarme sistemde yanal rijitliğin arttığını ve sistemin enerji sönümleme kapasitesini arttırdığını belirlemișlerdir [12]. Sutcu, Takeuchi ve Matsui, BÖÇ ve geleneksel çaprazlar ile güçlendirilmiş betonarme bir yapıyı incelemişlerdir [13]. Çalışmalarında BÖÇ ile güçlendirilmiș betonarme çerçevedeki yer değiştirmelerin gözle görülür derecede azaldığını, geleneksel çelik ile güçlendirilmiş sistemde dengeli olmayan histerik davranış gözlemlendiğinden BÖÇ’li çerçeve yapının daha avantajlı olduğunu sonucuna ulaşmışlardır.

$\mathrm{Bu}$ çalışma kapsamında, belirli bir düzende uygulanan BÖÇ elemanlar ile beraber tasarımı yapılmış olan 4 ve 8 katlı betonarme çerçeve sistemlerin 3 boyutlu doğrusal olmayan statik analiz ile deprem performansları belirlenerek, BÖÇ elemanlarının yapıya olan katkıları incelenmiştir.

\section{Burkulması Önlenmiş Çaprazlar (BÖÇ)}

Geleneksel çelik çaprazlı çerçevelere alternatif olarak kullanılan BÖÇ elemanlar (Şekil 3) özellikle deprem etkilerine karşı yapıda gerekli yanal stabiliteyi sağlamak amacı ile kullanılır. BÖÇ elemanlar yüksek derecede sünekliğe sahiptirler ve bu özellikleriyle önemli ölçüde enerji sönümleyebilme kabiliyetine sahiptirler [14]. Eksenel yükler altında burkulmadan akmaları ve plastik şekil değiştirebilmeleri önemli özelliklerindendir ve hesap tasarımları bu kabiliyete göre gerçekleştirilir [11]. 
B. Doran vd. / Betonarme Yapılarda Burkulması Önlenmiş Çapraz Elemanların Doğrusal Olmayan Davranışa Etkisi

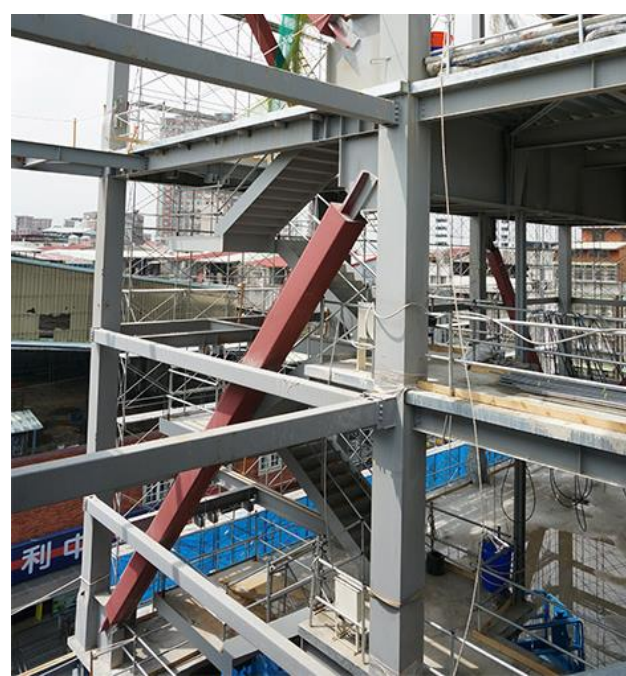

Şekil 3. Burkulması önlenmiş çapraz (BÖÇ) [15]

Geleneksel türdeki çelik çapraz elemanlar (GÇÇ) çevrimsel yükler altında asimetrik bir davranıș sergilemektedir (Şekil 4). Eksenel basınç kuvveti etkisi altındaki çubuk elemanlarda meydana gelen yanal burkulma, bir stabilite problemine neden olmaktadır. Bu durum çelik çaprazlarda çekme kuvveti kapasitelerine klyasla çok daha küçük eksenel basınç kuvvetleri değerlerinde taşıma özelliklerini kaybetmelerine neden olur [14]. Dolayısıyla, doğası gereği geleneksel çelik çapraz elemanların basınç ve çekme kapasiteleri arasında farklılıktan söz etmek mümkündür

[16].

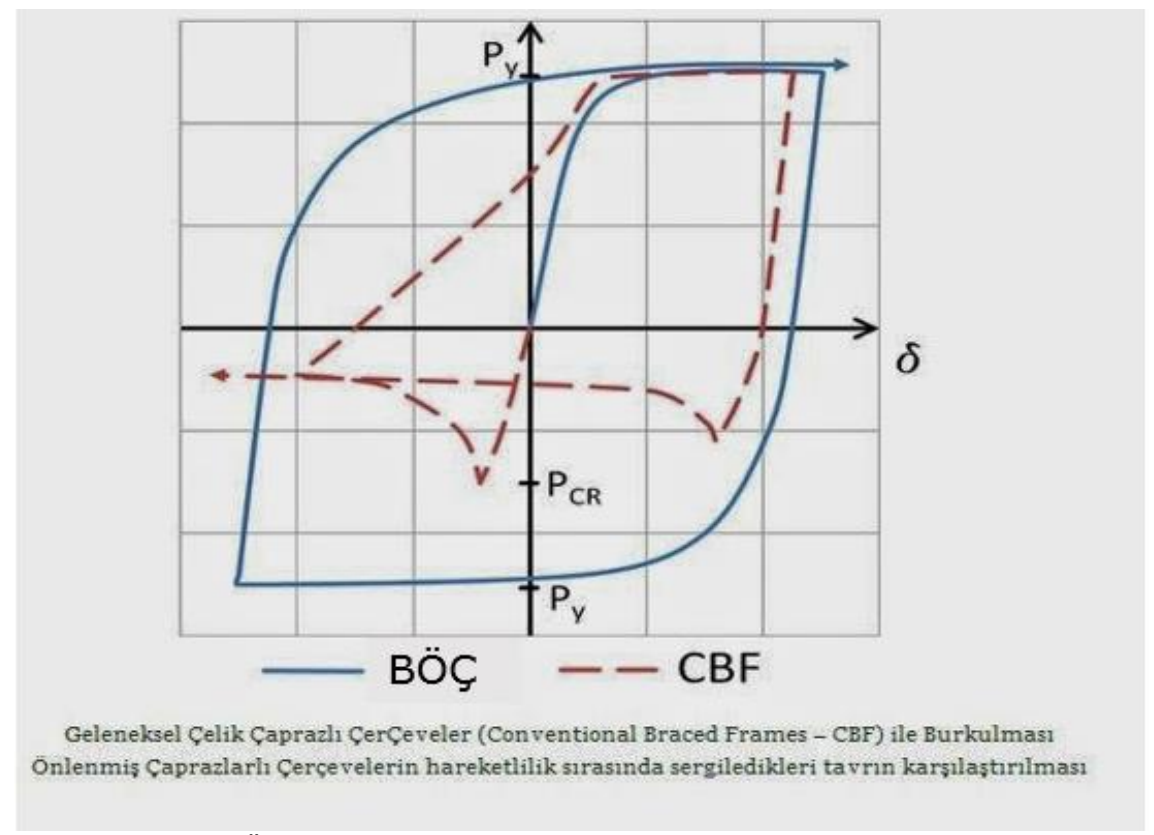

Şekil 4. BÖÇ-tipik histerik davranış eğrileri [17]

BÖÇ elemanların Şekil 5'de görüldüğü genel çalışma mekanizması dikkate alınacak olursa, çevrimsel yükler altında geleneksel çapraz elemanlara nazaran önemli ölçüde enerji sönümleme yeteneğine sahip daha kararlı ve oldukça sünek davranış sergileyeceği açıktır (Şekil 4)[18]. 
B. Doran vd. / Betonarme Yapılarda Burkulması Önlenmiş Çapraz Elemanların Doğrusal Olmayan Davranışa Etkisi

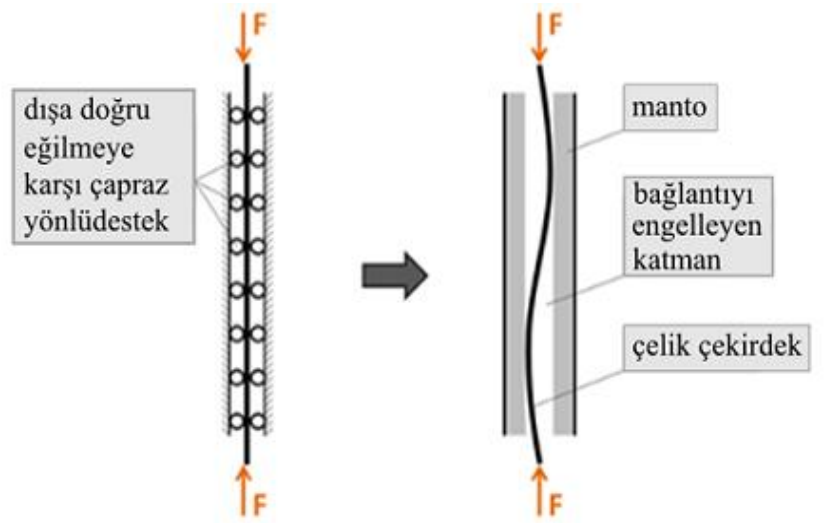

Şekil 5. BÖÇ elemanların çalışma mekanizması [17]

BÖÇ elemanların statik hesaplarda belirtilen aşağıdaki formüllerde kullanılacak karakteristik özellikleri AISC 341-10 [18] yönetmeliğine göre belirlenmektedir. $\mathrm{Bu}$ yönetmeliğe göre BÖÇ elemanların en büyük basınç ve çekme kuvveti taşıma kapasiteleri aşağıdaki formüllerle hesaplanır.

$$
\begin{gathered}
\mathrm{C}_{\max }=\omega * \beta * \mathrm{P}_{\mathrm{ysc}} \\
\mathrm{T}_{\max }=\omega * \mathrm{P}_{\mathrm{y} s c}
\end{gathered}
$$

Formüllerde yer alan $\omega$ değeri pekleșme düzeltme katsayısı, $\beta$ ise basınç kuvveti düzeltme katsayısıdır. BÖÇ elemanın çelik çekirdeğine ait eksenel kuvvet değeri de $P_{y s c}$ olarak formüllerde yer almaktadır.

BÖÇ elemanların uzama ve kısaltma kapasite değerleri ise AISC 341-10'da

$$
\begin{gathered}
\Delta_{\mathrm{bx}}=\left(\mathrm{P}_{\mathrm{bx}} * \mathrm{~L}_{y s c}\right) /\left(\mathrm{E} * \mathrm{~A}_{\mathrm{sc}}\right) \\
\Delta_{\mathrm{bm}}=\mathrm{C}_{\mathrm{d}} * \Delta_{\mathrm{bx}}
\end{gathered}
$$

BÖÇ elemanının akma uzunluğu olan Lysc üreticinin belirttiği boy değeri olup, $C_{d}$ değeri etkin yer değiştirme (süneklik) katsayısı olup testlerle elde edilmektedir.

Yukarıdaki formüllerle idealleştirilmiş BÖÇ elemanlarına ait tasarım kuvvet-yer değiştirme diyagramı Şekil 6'da gösterilmiştir.

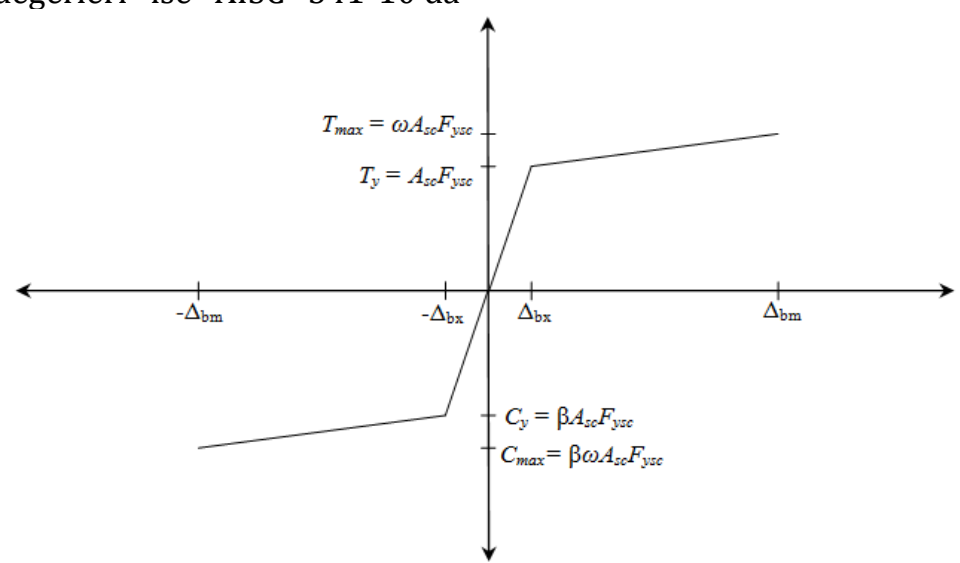

Şekil 6. BÖÇ elemanların eksenel kuvvet - yer değiştirme diyagramı [19] 


\section{Sayısal İrdemeler}

Çalışmada 4 ve 8 katlı betonarme çerçevelerin tasarımı TDY 2007 [19] esasları doğrultusunda, 3 farklı şekilde gerçekleştirilmiştir. Örnek olması açısından 4 katlı yapılar için düşey kesitler, Tip 1: yalın çerçeve, güçlendirilmiş çerçeveler-Tip 2: tek kat yükseklikli BÖÇ, Tip 3: çift kat yükseklikli BÖÇ, Şekil 7'de gösterilmiştir.

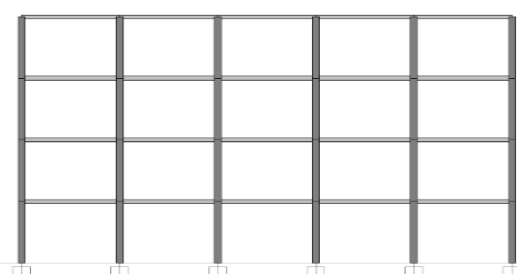

Tip 1:Yalın çerçeve sistem

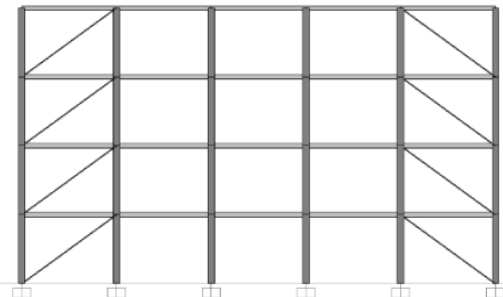

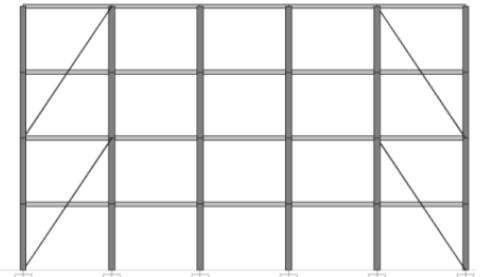

Tip 3: Çift kat yüksekliğinde BÖÇ

Şekil 7. Betonarme çerçeve ve BÖÇ düzeni

Betonarme yapı modellerinin genel özellikleri her üç sistemde de aynıdır. Bütün aks aralıkları $6 \mathrm{~m}$ olup $\mathrm{X}$ ve $\mathrm{Y}$ doğrultularında sırasıyla 6 adet aks bulunmaktadır. Toplam bina oturum alanı 900 m2'dir. Kat planlarının tüm katlar için farklılık göstermediği kabul edilmiş, kat yükseklikleri ise $4.2 \mathrm{~m}$ olarak dikkate alınmıştır. Uygulamada BöÇ elemanlarının montaj kolaylığı açısından döşeme sistemi kirişsiz döşeme olarak seçilmiştir. Döşeme kalınlığı 0.25 m'dir. Şekil 8'de yapının tipik kat planı görülmektedir.

Tip 2: Tek kat yüksekliğinde BÖÇ

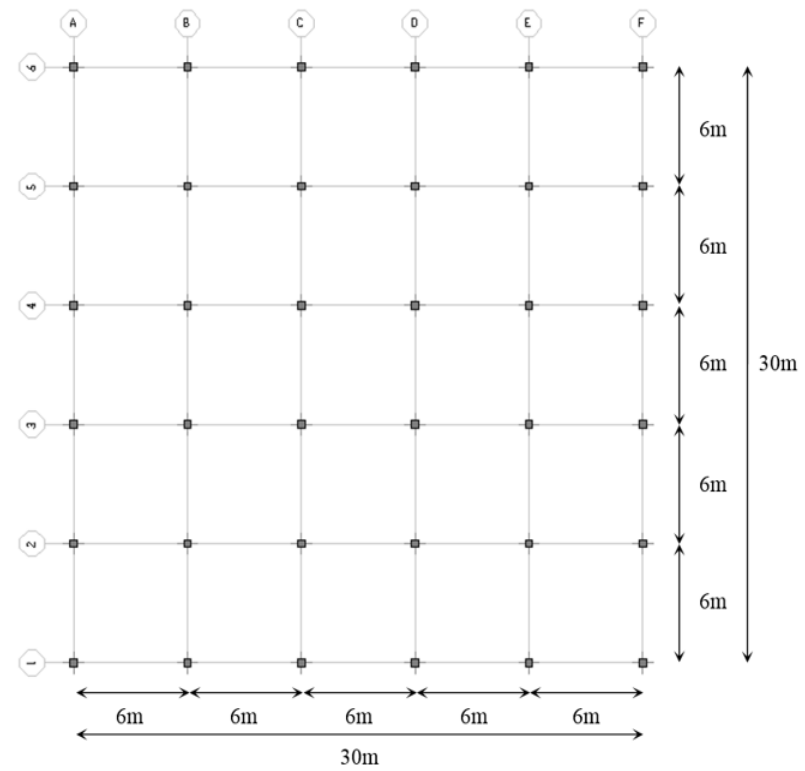

Şekil 8. Tipik kat planı 
Yapılarda kullanılan kolon kesit boyutları 40x40 cm'dir. Düşey donatı olarak $12 \phi 20$, etriye olarak $\phi 8 / 10$ kullanılmıştır (Şekil 9). Beton sınıfı olarak C30, çelik sınıfı olarak S420a seçilmiştir. TS500'e [20] dayanarak elastisite modülleri beton için $3.0 \times 10^{7} \mathrm{kN} / \mathrm{m}^{2}$, çelik için $2.0 \times 10^{8}$ $\mathrm{kN} / \mathrm{m}^{2}$ olarak dikkate alınmıştır.
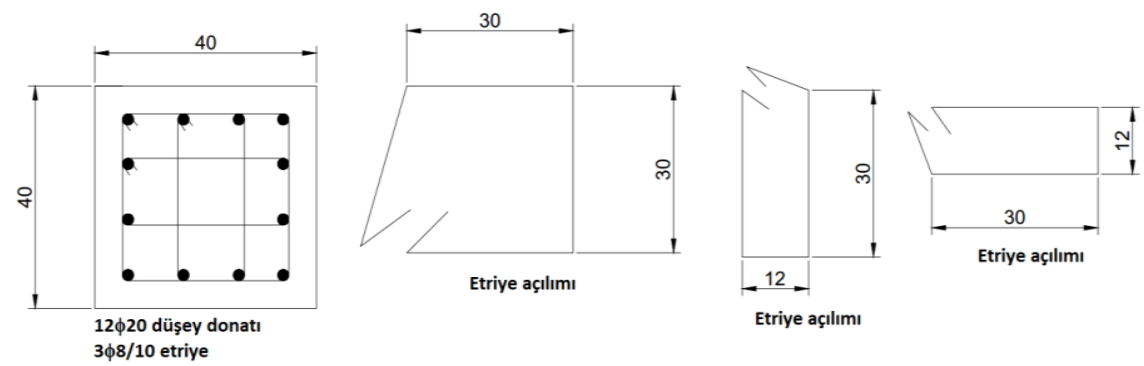

Şekil 9. Tipik kolon planı

Bölüm 3'de bahsedilmiş olan üç farklı yapı 1. Derece deprem bölgesinde olup zemin sınıfı Z4'dür. Sayısal modellerin 3 boyutlu doğrusal olmayan statik analizleri SAP $2000 \quad$ v14.2.2 $\quad$ sonlu elemanlar yazilımı [22] ile gerçekleștirilmiştir.

TDY 2007 esasları doğrultusunda gerçekleştirilen doğrusal olmayan performans analizleri sonucu yapının öngörülen performans hedefini sağlayamadığı belirlenmiștir. Bu nedenle mevcut yapılar BÖÇ elemanlar yardımıla iki farklı șekilde güçlendirilmiş ve yapıların (Tip 2 ve 3) sismik performansları ayrı ayrı araștırılmıștır. Așağıdaki bölümlerde analiz detayları verilmiștir.

\subsection{Katlı Betonarme Yapı}

Tip 1 yapı modelinin modal analiz sonuçlarına göre yapının hakim moda (Xdoğrultusu) ait periyodunun 1.479 saniye, bu moda ait kütle katılım oranının ise $\% 84$ olduğu görülmektedir. Tip 1 yapı modeline ait İtme analizi ve Modal Kapasite Diyagramı-Davranıș Spektrumu Şekil 11'de verilmiştir. TDY 2007 esasları doğrultusunda hesaplanan tepe noktası yatay yer değiştirmesi 0.370
Her üç tip yapıya ait sayısal modelde, betonarme kolonlar için P-M-M plastik mafsal kabulü yapılmıştır. Plastik mafsallar FEMA 356'ya [21] göre tanımlanmıştır. m'dir. Ayrıca 1-Aksı kolonları için hesaplanan eksenel kuvvet diyagramları Șekil 10'da verilmiștir.

Tip 2 yapı modelinde yapıda $\mathrm{X}$ doğrultusundaki diş akslara tek kat yüksekliğinde kesit alanı $20.25 \mathrm{~cm}^{2}$ ve boyu $7.32 \mathrm{~m}$ olarak boyutlandırılmış olan BÖÇ elemanlar ile güçlendirilmiştir. BÖÇ elemanlardaki eksenel yükler dikkate alınarak plastik mafsal özellikleri XTRACT [23] kesit analizi programı ile belirlenmiştir [24]. Bu durumda yapının hakim moda (X-doğrultusu) ait periyodu 1.034 saniye, kütle katılım oranı ise $\% 85$ dir. Modal Kapasite Diyagramı-Davranış Spektrumu Şekil 13'de görüldüğü gibidir. Hesaplanan tepe yer değiștirme istemi 0.238 m'dir. 1-Aksı kolonlarına ait eksenel kuvvetler Şekil 12'de verilmiştir. Tip 3 yapı modelinde ise yapıda $X$ doğrultusundaki dış akslara 2 kat yüksekliğinde kesit alanı $20.25 \mathrm{~cm}^{2}$ ve boyu $10.32 \mathrm{~m}$ olarak boyutlandırılmış olan BÖÇ elemanlar ile güçlendirilmiştir. Yapının X-doğrultusundaki hakim moda ait periyodu ve kütle katılım oranı sırasıyla 1.123 saniye ve \%85 olmaktadır. $\mathrm{Bu}$ duruma ait Modal Kapasite Diyagramı-Davranış Spektrumu Şekil 15'de görüldüğü gibidir. 
B. Doran vd. / Betonarme Yapılarda Burkulması Önlenmiș Çapraz Elemanların Doğrusal Olmayan Davranışa Etkisi

Hesaplanan tepe yer değiştirme istemi sonucu açığa çıkan eksenel kuvvetler 0.221 m'dir. 1-Aksı kolonlarında hesap Şekil 14'de görülmektedir.
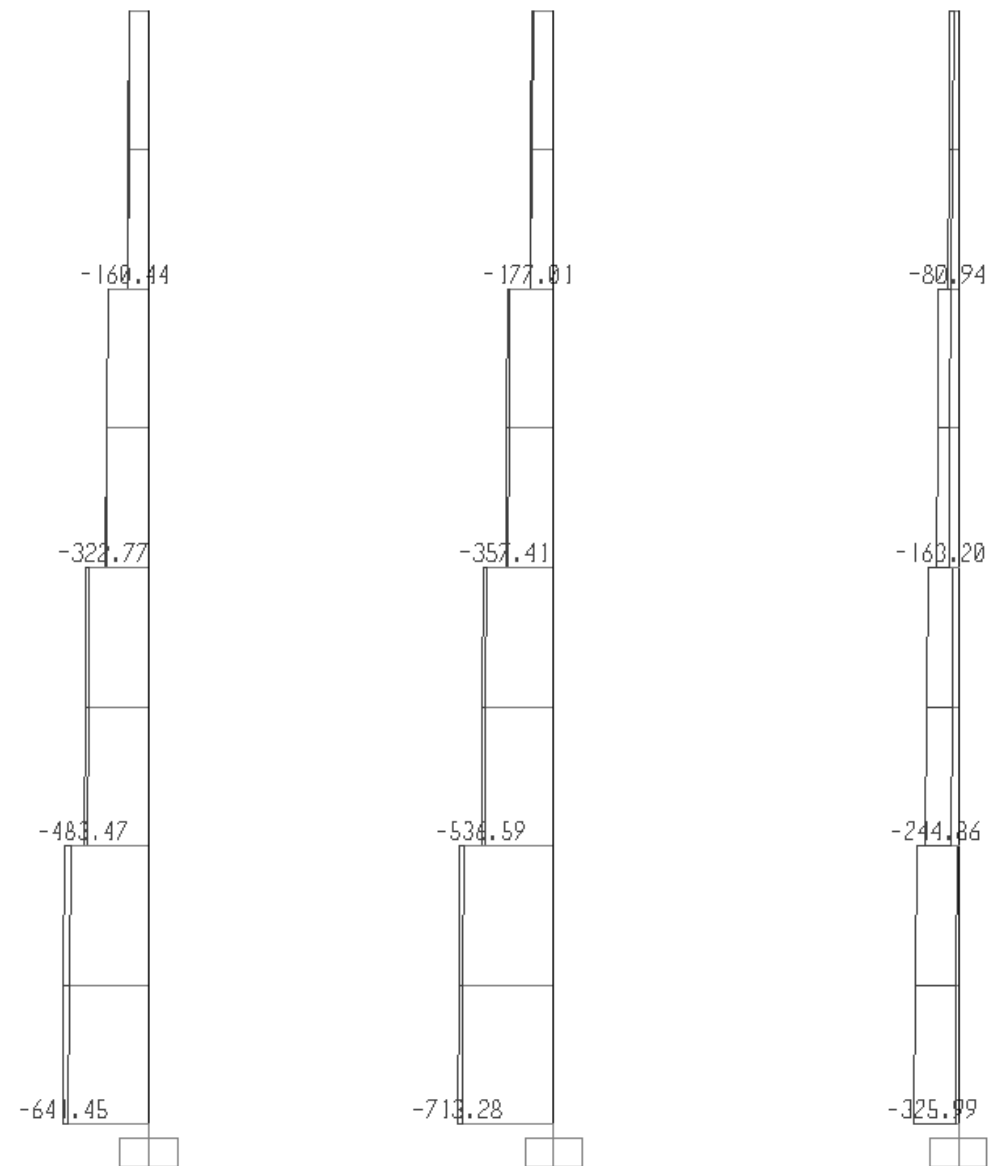

Şekil 10. Tip 1:1-Aksı kolonları eksenel kuvvet diyagramı(Birim:kN)
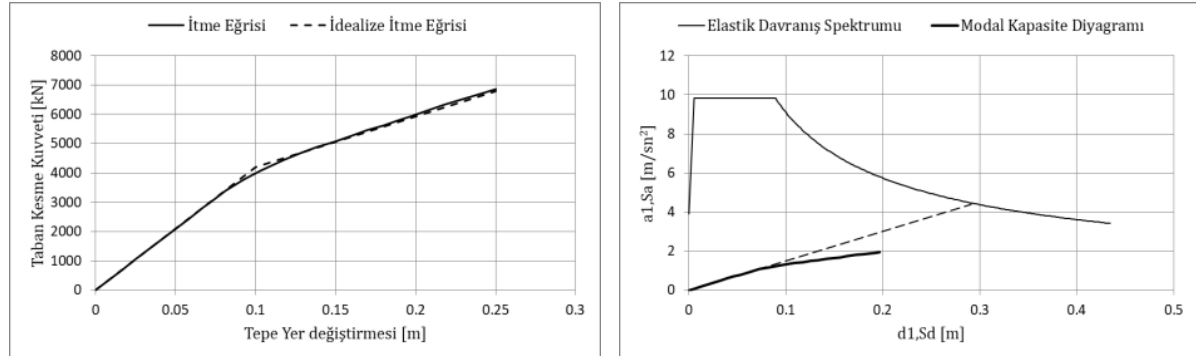

Şekil 11. a) Tip 1:X Doğrultusu itme eğrisi b)Tip 1:X Doğrultusu modal kapasite diyagramı-davranış spektrumu 
B. Doran vd. / Betonarme Yapılarda Burkulması Önlenmiş Çapraz Elemanların Doğrusal Olmayan Davranışa Etkisi
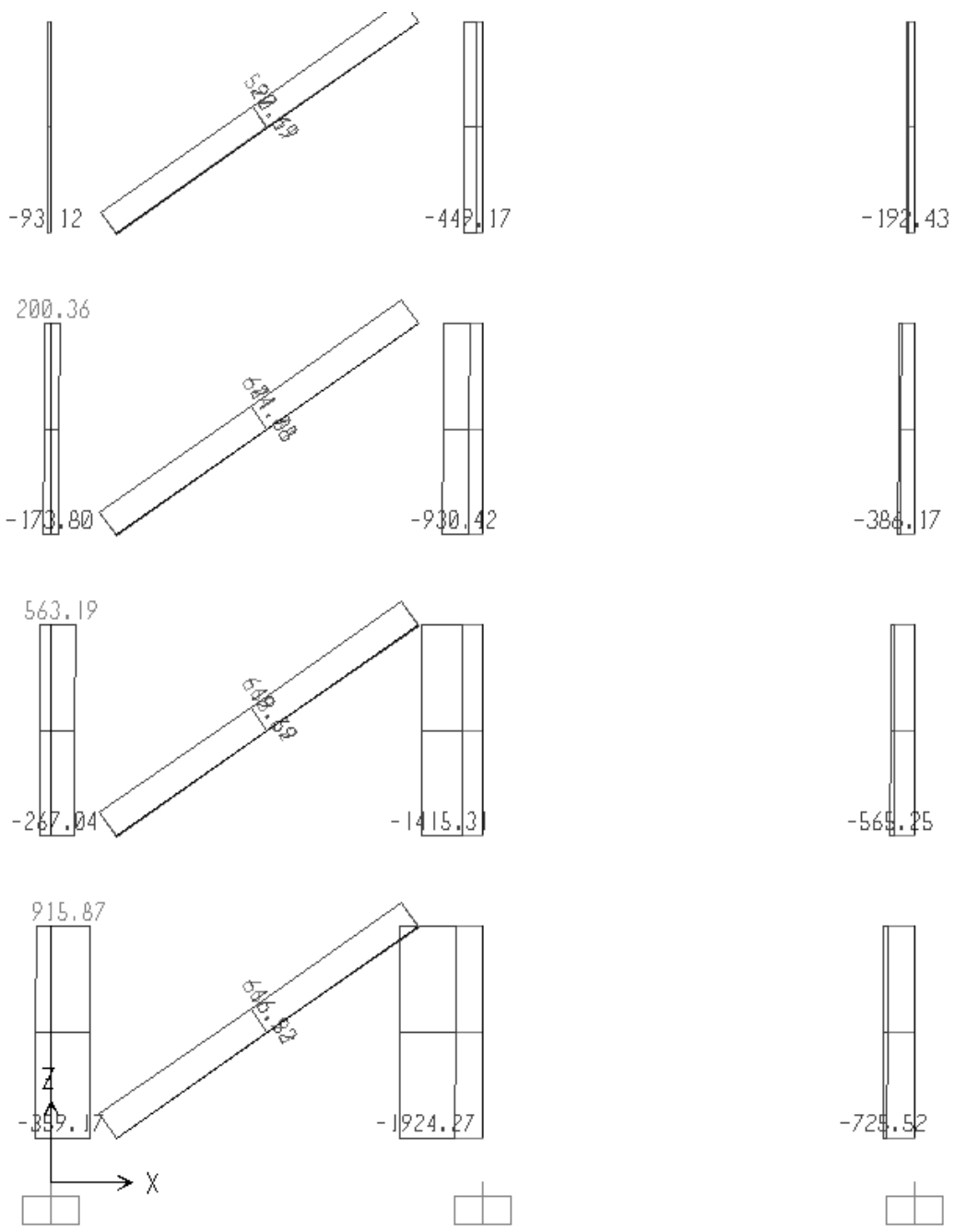

Şekil 12. Tip 2:1-Aksı kolonları eksenel kuvvet diyagramı(Birim:kN)
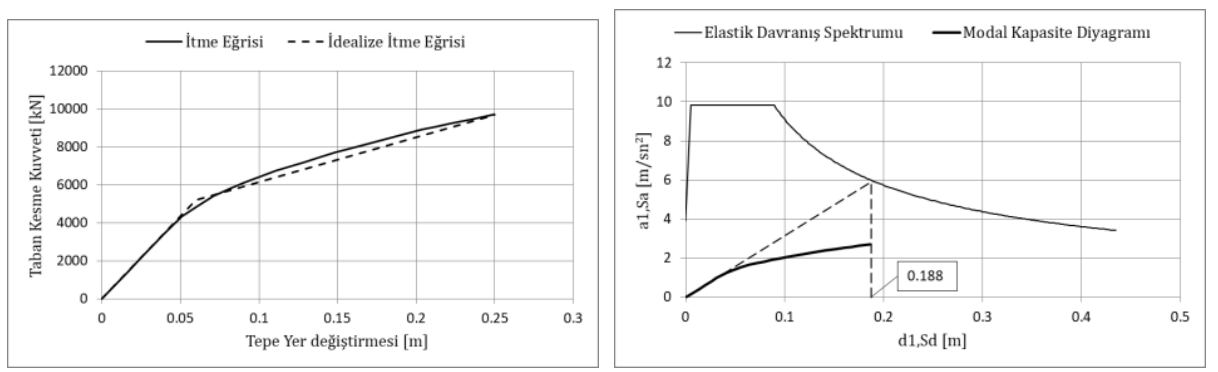

Şekil 13. a) Tip 2:X Doğrultusu itme eğrisi b)Tip 1:X Doğrultusu modal kapasite diyagramı-davranış spektrumu 
B. Doran vd. / Betonarme Yapılarda Burkulması Önlenmiş Çapraz Elemanların Doğrusal Olmayan Davranıșa Etkisi
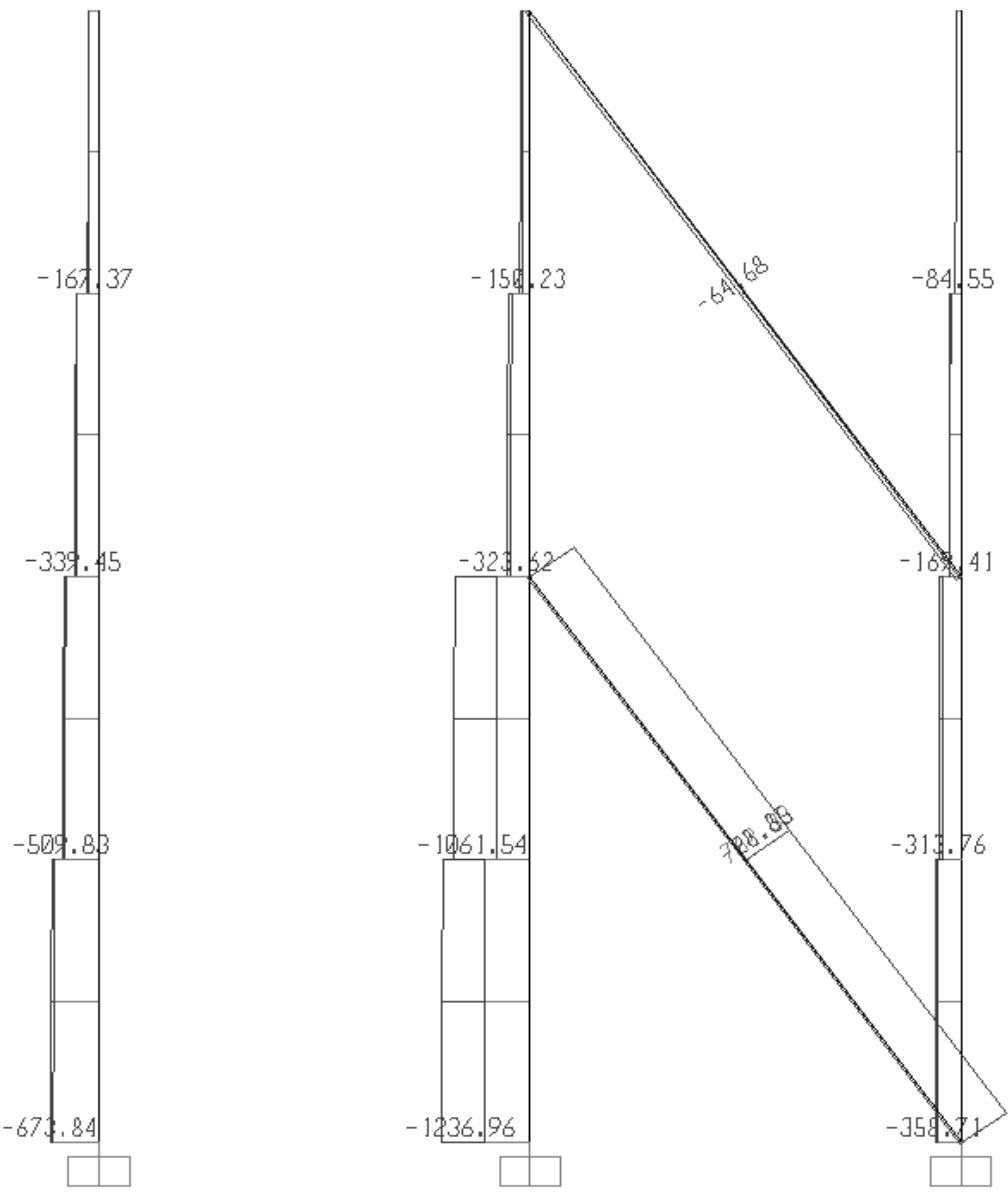

Şekil 14. Tip 3:1-Aksı kolonları eksenel kuvvet diyagramı(Birim:kN)
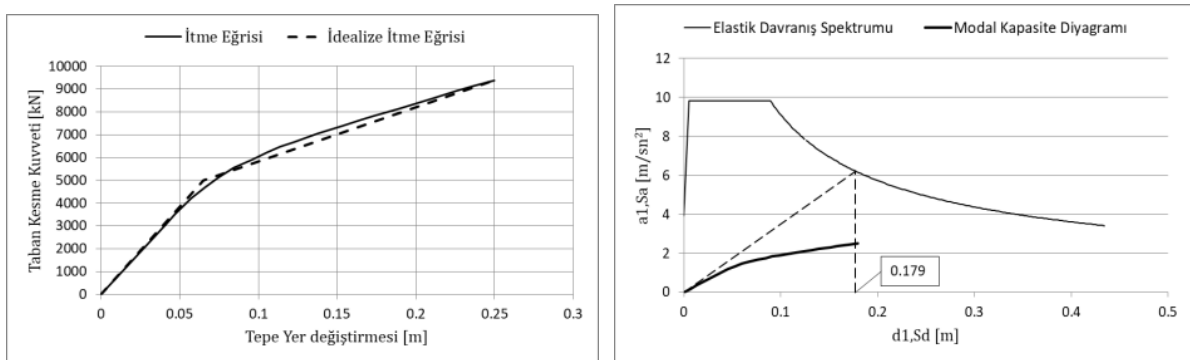

Şekil 15. a) Tip 3:X Doğrultusu itme eğrisi b)Tip 1:X Doğrultusu modal kapasite diyagramı-davranıș

spektrumu

Tip 2 ve Tip 3 yapı modellerinde en büyük eksenel yüke maruz kalan kolonlar için TDY 2007 esasları doğrultusunda gerçekleștirilmiş olan şekil değiştirme esaslı performans değerlendirilmesi sonucu anılan kolonlara ait hasar seviyeleri sırası ile Şekil 16 ve Şekil 17'de gösterilmiştir. Șekil 11 ve 13'den anlașıldı̆̆ üzere maksimum eksenel yük değerleri sirasıyla $1924 \mathrm{kN}$ ve $1237 \mathrm{kN}$ olarak hesaplanmıștır. Bu durumda Tip 2 ve Tip 
B. Doran vd. / Betonarme Yapılarda Burkulması Önlenmiş Çapraz Elemanların Doğrusal Olmayan Davranışa Etkisi

3 için anılan kolonlar minimum hasar kalmıştır. bölgesini aşıp güvenlik sınırında

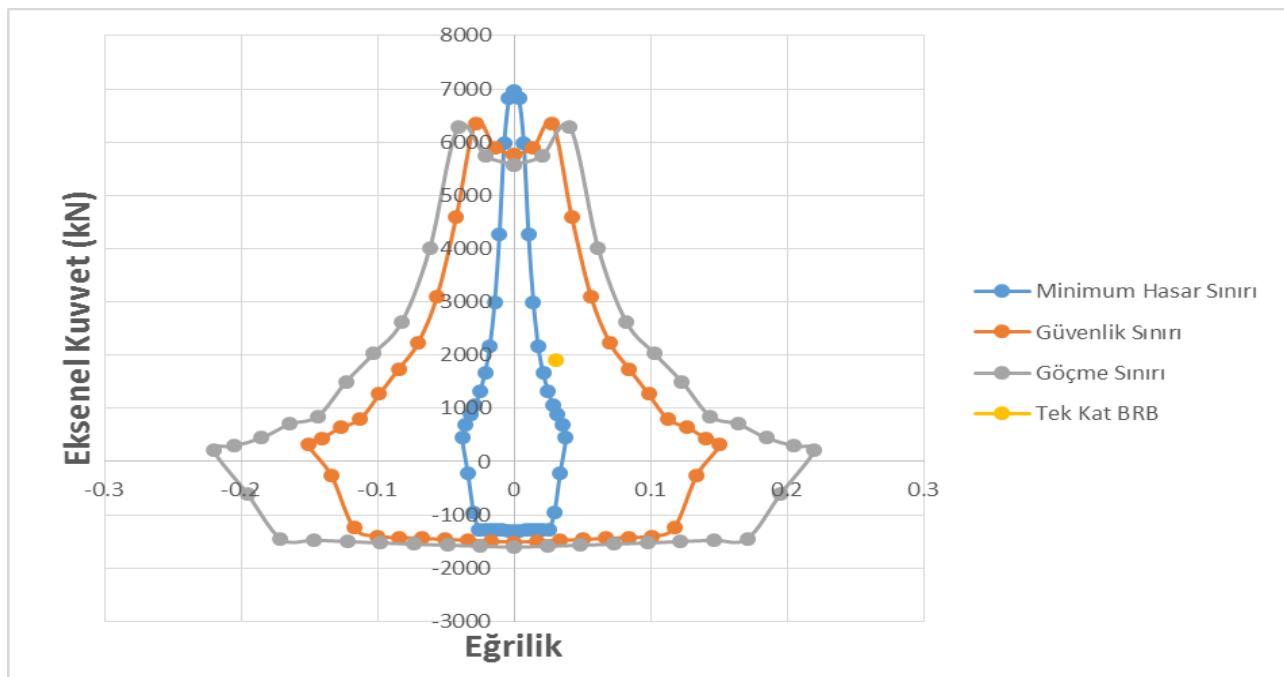

Şekil 16. Tip 2- Hasar seviyeleri için toplam eğrilik limitleri

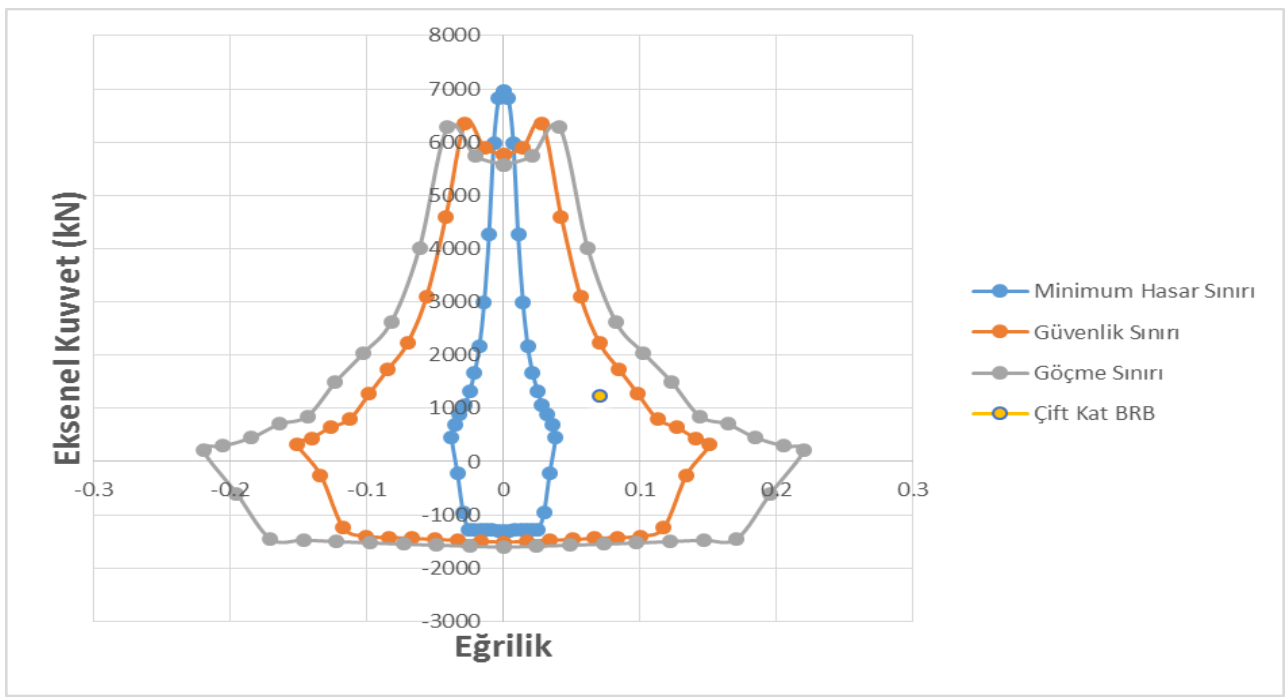

Şekil 17. Tip 3- Hasar seviyeleri için toplam eğrilik limitleri

\subsection{Katlı Betonarme Yapı}

8 katlı betonarme yapı modellerinde Tip 2 ve Tip 3 çerçeve düzenlerine sahip iki sistem incelenmiştir. Tip 2 yapı modelinde yapıda $\mathrm{X}$ doğrultusundaki dış akslara tek kat yüksekliğinde ve kesit alanı $56.25 \mathrm{~cm}^{2}$ olan $7.32 \mathrm{~m}$. uzunluğa sahip BÖÇ elemanlar eklenmiştir. Modal Kapasite Diyagramı - Davranış
Spektrumu Sekil 18'de verilmiștir. Hesaplanan tepe yer değiştirme istemi 0.323 m.'dir. Tip 3 yapı modelinde ise yapıda X doğrultusundaki dış akslara 2 kat yüksekliğinde ve kesit alanı 56.25 $\mathrm{cm}^{2}$ ve boyu $10.32 \mathrm{~m}$. olarak boyutlandırılmış BÖÇ elemanlar ilave edilmiştir. Bu duruma ait Modal Kapasite Diyagramı - Davranış Spektrumu Şekil 
B. Doran vd. / Betonarme Yapılarda Burkulması Önlenmiș Çapraz Elemanların Doğrusal Olmayan Davranıșa Etkisi

19'da görüldüğü gibidir. Hesaplanan tepe belirlenmiştir yer değiştirme istemi ise $0.238 \mathrm{~m}$. olarak
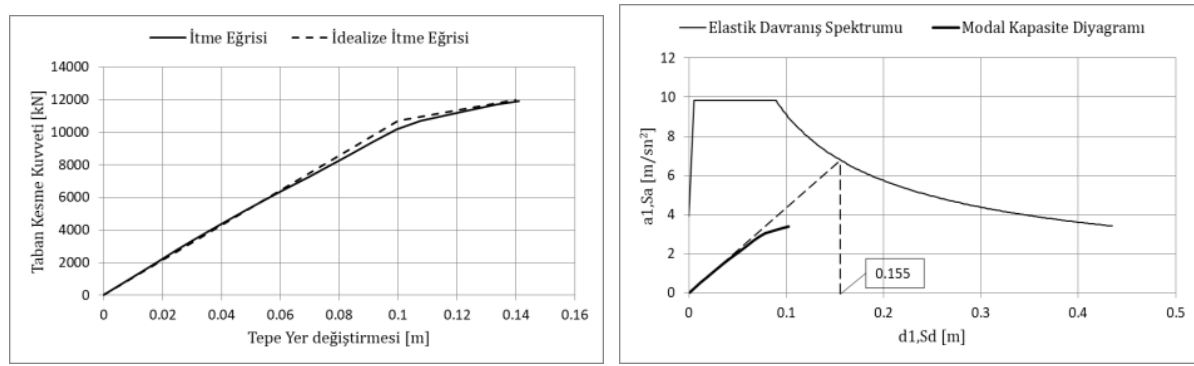

Şekil 18. a) Tip 2:X Doğrultusu itme eğrisi b)Tip 1:X Doğrultusu modal kapasite diyagramı-davranış spektrumu
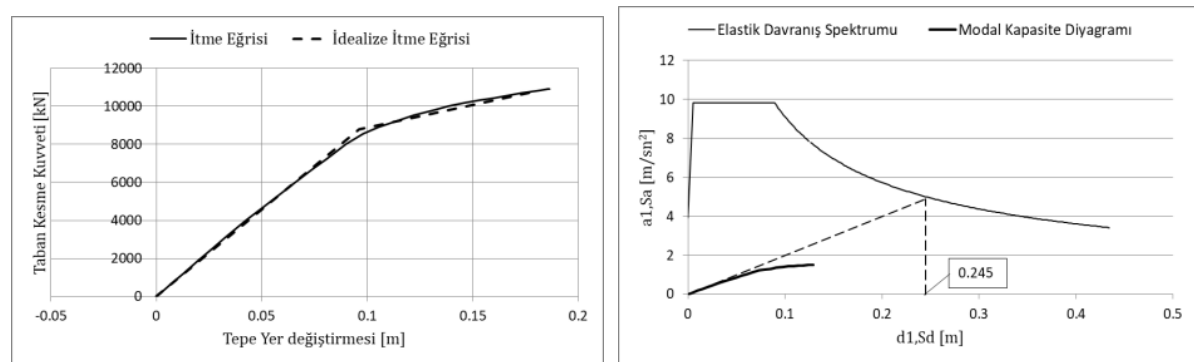

Şekil 19. a) Tip 3:X Doğrultusu itme eğrisi b)Tip 1:X Doğrultusu modal kapasite diyagramı-davranış spektrumu

Tip 2 ve Tip 3 yapı modellerinde en büyük eksenel yüke maruz kalan kolonlar için TDY 2007 esasları doğrultusunda gerçekleştirilmiş olan șekil değiștirme esaslı performans değerlendirilmesi sonucu anılan kolonlara ait hasar seviyeleri sirası ile Şekil 21 ve Şekil 22'de gösterilmiştir.
Șekil 20'den anlașıldığı üzere maksimum eksenel yük değerleri sırasıyla $6401 \mathrm{kN}$ ve $5709 \mathrm{kN}$ olarak hesaplanmıştır. Bu değerlere göre Tip 2 ve Tip 3 modelleri için anılan kolonlar minimum hasar bölgesini aşıp güvenlik sınırında kalmıştır. 
B. Doran vd. / Betonarme Yapılarda Burkulması Önlenmiş Çapraz Elemanların Doğrusal Olmayan Davranışa Etkisi

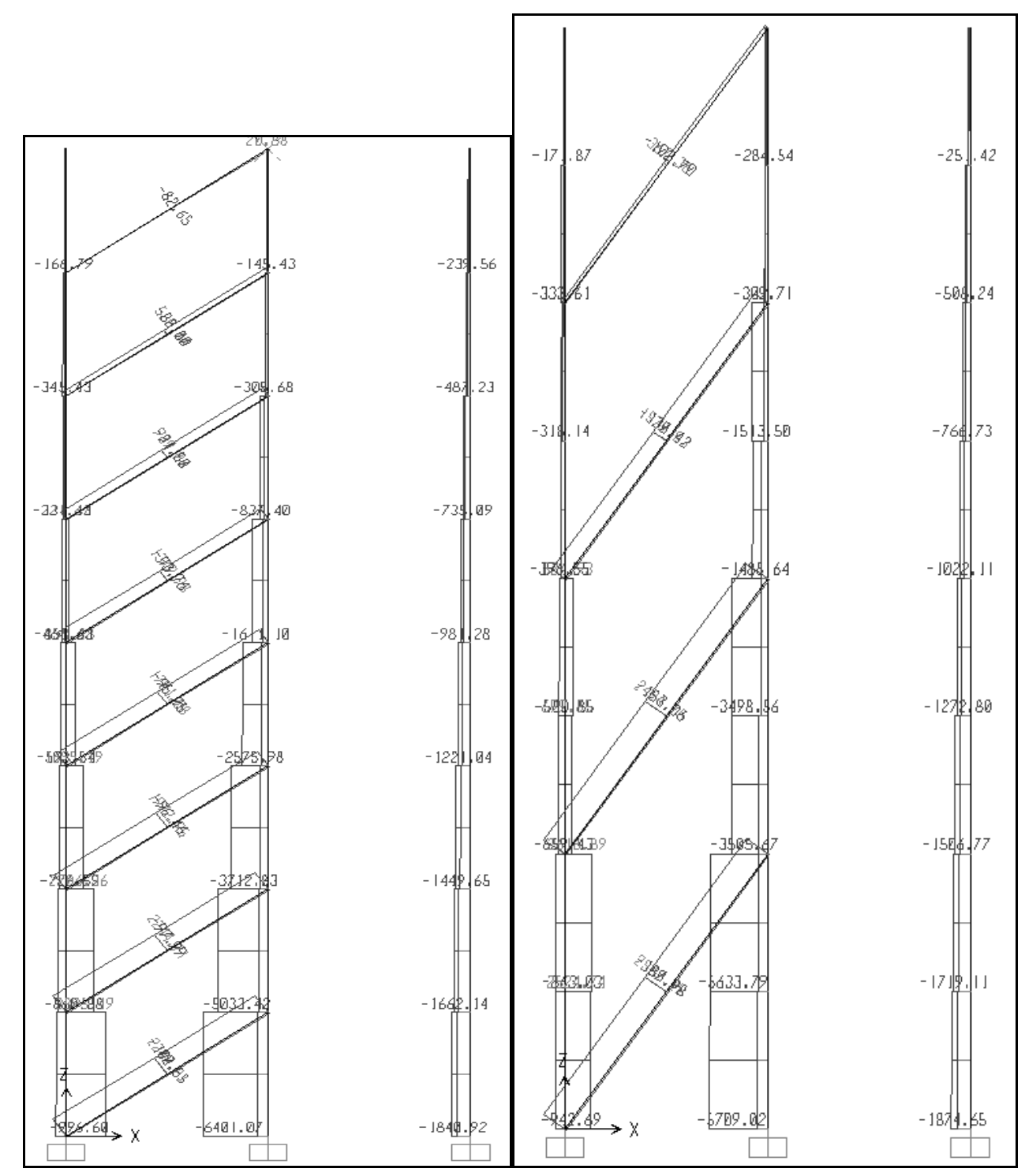

a. Tip 2

b. Tip 3

Şekil 20. 1-Aksı kolonları eksenel kuvvet diyagramı(Birim:kN) 

Etkisi

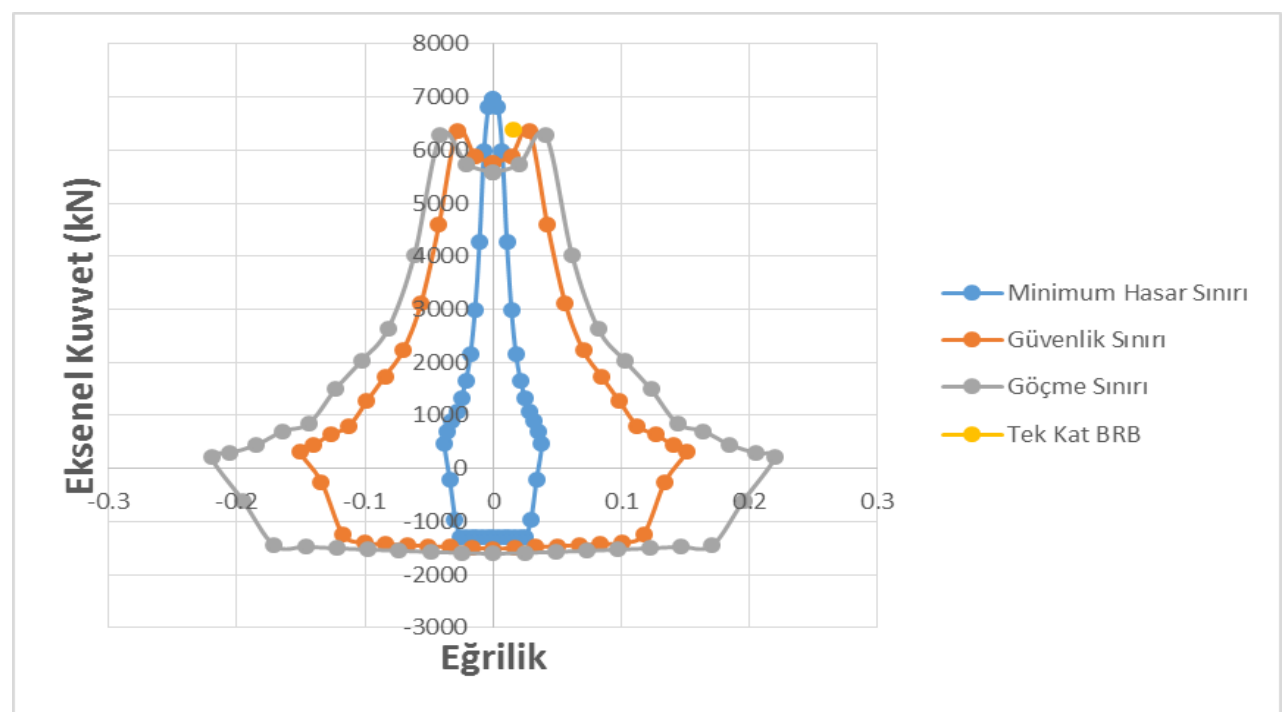

Şekil 21. Tip 2- Hasar Seviyeleri İçin Toplam Eğrilik Limitleri

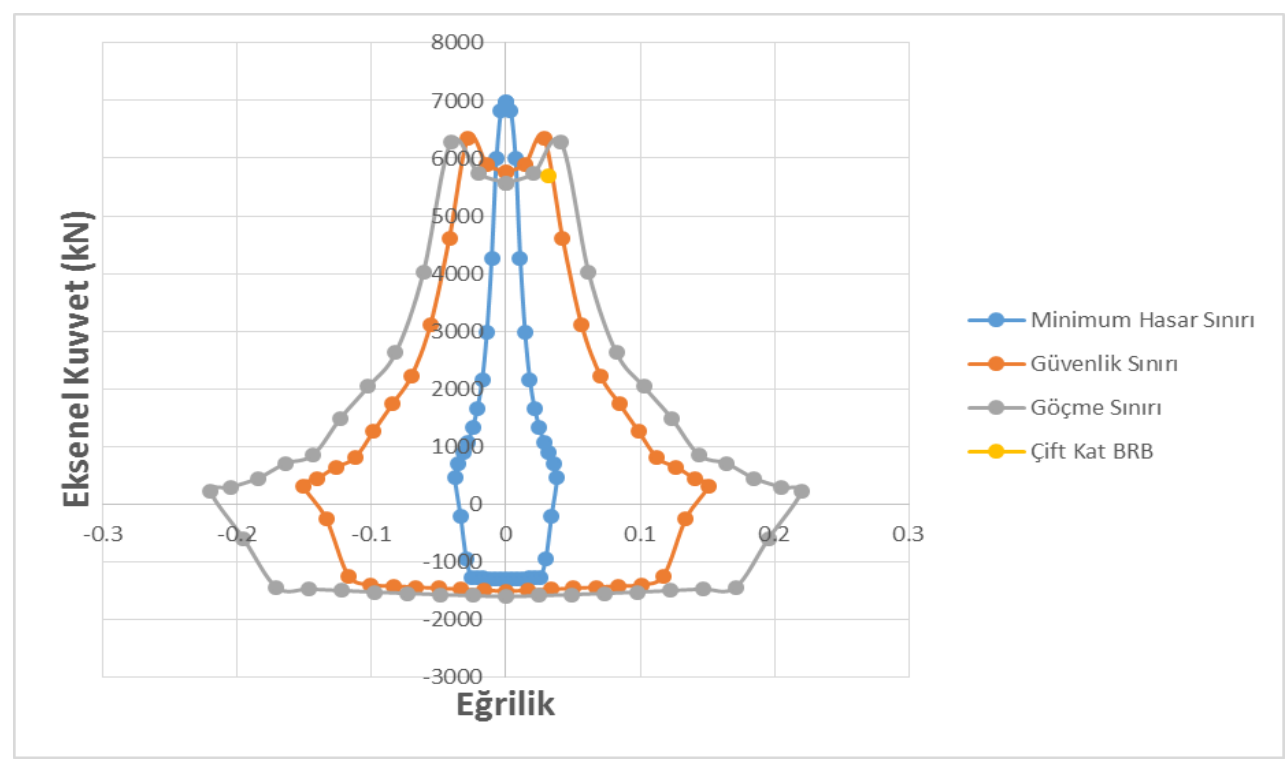

Şekil 22. Tip 3- Hasar Seviyeleri İçin Toplam Eğrilik Limitleri

\section{Sonuçlar}

Bu çalışmada, farklı teknikte uygulanan BÖÇ elemanlarla güçlendirilmiș 4 katlı ve 8 katlı yapıların (az/orta-katlı), 3 boyutlu doğrusal olmayan statik analizleri gerçekleştirilerek BÖÇ elemanlarla sağlanan yapısal performans irdelenmiştir. Buna göre, (a) 4 katlı yapı modelinde Tip 2 çerçeve sistemi ile ulaşılan maksimum tepe yer değiştirme değerinin Tip 1'e göre yaklaşık \%36 oranında azaldığı, Tip 3 çerçeve sistemi ile ise bu oranın yaklaşık \%40 mertebesinde kaldığı, ancak BÖÇ elemanların bağlandığı kolonlarda eksenel yük değerlerinde önemli oranda bir artışın meydana geldiği görülmüștür,

(b) 8 katlı yapı modelleri incelendiğinde Tip 2 çerçeve sisteminin Tip 1 çerçeve sistemine göre \%26 daha az tepe yer değiştirme istemine sahip olduğu 
analizler sonucunda ortaya çıkmıştır. Kolonlardaki eksenel normal kuvvet değerlerinin ise her iki yapı modelinde birbirine yakın olduğu görülmektedir.

(c) BÖÇ elemanların bağlandığ kolonlarda her ne kadar eksenel kuvvetler artmış olsa da, birim şekil değiştirmelerden hareketle gerçekleştirilen performans değerlendirmeleri sonucu, bu kolonlarda hasar oluşumunun belirgin hasar ile sınırlı kaldığı görülmüștür.

(d) BÖÇ elemanlarla gerçekleştirilen her iki güçlendirme şeklinde de yer değiştirme istemleri mevcut yapıdakine oranla azaldığı aşikârdır. Ancak BÖÇ elemanların bağlandığı kolonlarda eksenel yükler açısından kritik değerlere ulaşılabilmektedir. Anılan kolonlarda her ne kadar hasar oluşumu istenen sınırlar içerisinde kalsa da bu kolonlarda sünek davranışı artırmak üzere ilave önlemlerin alınması şart olacaktır.

\section{Kaynakça}

[1] https://www.thebig5hub.com/inn ovation/2015/february/ebsbrings-the-latest-steel-braceinnovation-to-mena/

[2] http://eralpyapi.com/urundetay/celik-konstruksiyon-ev\#gallery-20

[3] Yoshino T, Karino Y. 1971. Experimental study on shear wall with braces: Part 2, Summaries of technical papers of annual meeting, Architectural Institute of Japan, Structural Engineering Section, Cilt 11. S.403-404.

[4] Goel S.C, Lee H.S. 1990. Seismic strengthening of RC structures by ductile steel bracing system. Proceedings of Fourth U.S National Conference on Earthquake.

[5] Maheri M, Sahebi A. 1997. Use of steel bracing in reinforced concrete frames. Engineering Structures, Cilt.19, No.12, s.1018-
1024. DOI: $10.1016 / S 0141-$ 0296(97)00041-2

[6] Kim J, Choi H. 2004. Behavior and design of structures with bucklingrestrained braces, Engineering Structures, Cilt.26, No.6, s.693-706. DOI:

10.1016/j.engstruct.2003.09.010

[7] Qiang X. 2005. State of the art of buckling-restrained braces in Asia. Journal of Constructional Steel Research, Cilt.61, s.727-748. DOI: $10.1016 /$ j.jcsr.2004.11.005

[8] Chang H.Y, Chiu C.K. 2011. Performance Assessment of Buckling Restrained Braces. Procedia Engineering, Cilt.14, s.2187-2195. DOI: 10.1016/j.proeng.2011.07.275

[9] Almansa F.L, Medina J.C, Oller S. 2012. A numerical model of the structural behavior of buckling restrained braces, Engineering Structures, Cilt.41, s.108-117. DOI: 10.1016/j.engstruct.2012.03.045

[10] Hoveidae N, Rafezy $\quad$ B. 2012. Overall buckling behavior of allsteel buckling restrained braces, Journal of Constructional Steel Research, Cilt.79, s.151-158. DOI: 10.1016/j.jcsr.2012.07.022

[11] Khampanit A, Leelataviwat S, Kochanin J, Pennung Warnitchai P. 2014. Energy-based seismic strengthening design of nonductile reinforced concrete frames using buckling-restrained braces, Engineering Structures, Cilt.81, s.110-122 DOI: 10.1016/j.engstruct.2014.09.033

[12] Zhang J, Wu B, Mei Y, Shing P.B. 2015. Experimental and Analytical Studies on a Reinforced Concrete Frame Retrofitted with BucklingRestrained Brace and Steel Caging, Advances in Structural Engineering, Cilt.18, No.2. s.155171. DOI: $10.1260 / 1369$ 4332.18.2.155 
B. Doran vd. / Betonarme Yapılarda Burkulması Önlenmiş Çapraz Elemanların Doğrusal Olmayan Davranışa Etkisi

[13] Sutcu, F, Takeuchi T, Matsui R. 2014. Seismic retrofit design method for RC buildings using buckling-restrained braces and steel frames, Journal of Constructional Steel Research, Cilt.101, s.304-313. DOI: 10.1016/j.jcsr.2014.05.023

[14] Deren H, Uzgider E, Piroğlu F, Çağlayan Ö.B. 2008. Çelik Yapılar, 3. Baskl, Çağlayan Kitabevi, İstanbul, 984s.

[15] http://www.graysonengineering.co.nz/images/board/f ullsize/Photo\%2019c.jpg

[16] Hussain S, Benschoten P.V, Satari M.A, Lin S. 2013. Buckling Restrained Braced Frame (BRBF) Structures: Analysis, Design and Approvals Issues. Coffman Engineers, Inc. Los Angeles, CA.

[17] http://insaatteknigi.blogspot.com.t r/2014/06/burkulmas-onlenmiscelik-caprazlar.html

[18] AISC 341-10. 2010. Seismic Provisions for Structural Steel Buildings, American Institute of Steel Construction, Chicago, Illinois.

[19] Doran, B, Akbaş B, Şenol E, Şeker O. 2013. Non-linear static analysis of strengthened existing RC frame building using steel braces, Earthquake Engineering and Structural Dynamics, Viyana, Avusturya.

[20] Robinson K, Stocking A. 2013. Buckling Restrained Braces-An Overview.

[21] TSC-2007, 2007. Deprem Bölgelerinde Yapılacak Yapılar Hakkında Yönetmelik, Bayındırlık Bakanlığı, Ankara.

[22] TS500, 2000. Betonarme Yapıların Tasarım ve Yapım Kuralları, Bakanlıklar, Ankara.

[23] FEMA 356, 2000. Prestandard and Commentary for the Seismic Rehabilitation of Buildings,
American Society of Civil Engineers, Reston, Virginia.

[24] Sap2000 v14.2.2, 2010. Integrated Structural Analysis and Design Software, Computer and Structures Inc., Berkeley, California.

[25] XTRACT ver.3.0.8, 2007. Cross Sectional Analysis of Components, Imbsen Software System, Sacramento.

[26] Şenol E, Köse İ, Doran B, Mezrea P. E, Akbaş, B, 2015. Ductility Enhancement in Reinforced Concrete Structure with BucklingRestrained Braced Frames, Advances in Civil and Infastructure Engineering, 12-13 Haziran, Vietri Sul Mare, İtalya.

[27] Yön B, Sayın E. 2011. Betonarme Perdeler ve Çelik Çaprazlarla Yapılan Güçlendirmelerin Karşılaştırılması, Turkiye, 6th International Advanced Technologies Symposium (IATS'11), Elazı $\breve{g}$

[28] FEMA 450, 2003. NEHRP Recommended Provisions for Seismic Regulations for New Buildings and Other Structures, Federal Emergency Management Agency, Washington, D. C.

[29] AISC 360-10. 2010. Specification for Structural Steel Buildings, American Institute of Steel Construction, Chicago, Illinois. 